\title{
The White Barley Mutant Albostrians Shows a Supersusceptible but Symptomless Interaction Phenotype with the Hemibiotrophic Fungus Bipolaris sorokiniana
}

\author{
Patrick Schäfer, Ralph Hückelhoven, and Karl-Heinz Kogel \\ Interdisciplinary Research Centre for Environmental Sciences, Institute of Phytopathology and Applied Zoology, \\ Justus-Liebig University, Heinrich-Buff-Ring 26-32, D-35392 Giessen, Germany
}

Submitted 14 July 2003. Accepted 24 November 2003.

\begin{abstract}
Bipolaris sorokiniana (teleomorph: Cochliobolus sativus) is a cereal pathogen of increasing global concern, with most significance in Asiatic cropping systems. In order to gain insight into the mechanism of host resistance, we studied fungal development on the supersusceptible barley mutant albostrians and its parent cv. Haisa. A microscopic dissection of early fungal growth on Haisa and green albostrians leaves revealed a distinct epidermis-localized biotrophic and a mesophyll-based necrotrophic phase. White, green, and striped white-green albostrians leaves showed extreme differences in disease development. When comparing cellular defense responses, we found restriction of fungal spreading after successful infection of host mesophyll tissue to be the most important mechanism limiting outbreak of the disease. Colonization of susceptible green leaves, but not extreme colonization of supersusceptible white albostrians leaves, was associated with macroscopically visible lesion formation and mesophyll accumulation of hydrogen peroxide $\left(\mathrm{H}_{2} \mathrm{O}_{2}\right)$, implying a symptomless growth of the pathogen in supersusceptible host tissue. In contrast, early epidermal papilla-based resistance was closely linked to $\mathrm{H}_{2} \mathrm{O}_{2}$ accumulation in all leaf types. In white leaves, ascorbate peroxidase $(A P X)$, glutathione-S-transferase $(G S T)$, and the cell death regulator Bax-inhibitor-1 (BI-1) showed a stronger constitutive or pathogen responsive activation, whereas glycolate oxidase $(G L O X)$ and catalase (CAT2) expression was stronger in green leaves. We discuss supersusceptibility and symptomless growth on the basis of the histochemical and the gene expression data.
\end{abstract}

Additional keywords: cell wall apposition, hypersensitive response, necrotrophy, spreading factor.

Bipolaris sorokiniana, the causal agent of cereal spot blotch, root rot, crown rot, and black point, is responsible for severe yield losses worldwide. Infected leaves show dark brown oval

Corresponding author: K.-H. Kogel; Fax: +49-641-9937499; E-mail: Karl-Heinz.Kogel@agrar.uni-giessen.de

Nucleotide and amino acid sequence data are available from the GenBank database under accession numbers AJ234400 for the actin, AJ006358 for the ascorbate peroxidase, AJ290421 for the Bax inhibitor-1, U20778 for the catalase2, BG344206 for the glutathion-S-transferase, BE559255 for the glycolate oxidase $(87 \%$ homology to AF022740, O. sativa), and X74940 for PR-1b. lesions, which consist of clusters of dead mesophyll cells and leaf chlorosis. Harmfulness of B. sorokiniana might be explained by its ability to infect different plant parts such as roots, ears, and leaves during all plant growth stages. Moreover, $B$. sorokiniana shows a broad host spectrum within the gramineous plants, including the important crops wheat and barley (Kumar et al. 2002). The fungus builds disease complexes (e.g. with tan spot fungus, Pyrenophora tritici-repentis), resulting in so-called Helminthosporium leaf blight on wheat leaves (Dubin and Ginkel 1991), thereby enhancing its devastating potential considerably. The fungus produces toxins that might facilitate plant infestation, suggesting a necrotrophic lifestyle (Apoga et al. 2002; Briquet et al. 1998).

Despite the relevance of $B$. sorokiniana in cropping systems, little attention has been paid to cellular plant defense mechanisms (Dehne and Oerke 1985). In a previous study on barley, we found an association of hydrogen peroxide $\left(\mathrm{H}_{2} \mathrm{O}_{2}\right)$ accumulation and hypersensitive cell death with fungal arrest at early interaction stages. However, because genotypes with significant resistance do not exist in barley, it was difficult to define causal defense reactions (Kumar et al. 2001, 2002). The present study focuses on a comparison of defense mechanisms to foliar spot blotch in the differentially reacting barley albino mutant albostrians and its parent cv. Haisa. Albostrians has been characterized genetically as a nuclear-gene induced plastome mutant leading to a phenotypic expression of white, striped white-green, and green leaves (Boldt et al. 1997; Hess et al. 1998). In a first survey, we found that white leaf mutation results in a "supersusceptible" interaction phenotype with $B$. sorokiniana and, surprisingly, in resistance against the biotrophic powdery mildew fungus (Jain et al. 2004).

In a histochemical analysis, we determined lesion formation and $\mathrm{H}_{2} \mathrm{O}_{2}$ accumulation in the differentially reacting barley genotypes. Although the role of $\mathrm{H}_{2} \mathrm{O}_{2}$ in the interaction of plants with biotrophic fungi like the powdery mildew fungus has been studied extensively, its role in necrotrophy is unclear (Hückelhoven and Kogel 2003; Kumar et al. 2001, 2002). $\mathrm{H}_{2} \mathrm{O}_{2}$, involved in cell wall fortification and hypersensitive response (HR), hampers fungal infection and, additionally, plays a role as signal for defense gene activation (Grant and Loake 2000; Hückelhoven et al. 1999; Lamb and Dixon 1997; Levine et al. 1994; Mullineaux et al. 2000; Neill et al. 2002). On the other hand, necrotrophic fungi like Botrytis cinerea and Pyrenophora spp. seem to trigger reactive oxygen intermediates in their hosts to facilitate plant infestation (Govrin and Levine 2000, von Gönner and Schlösser 1993, 
von Tiedemann 1997). Thus, $\mathrm{H}_{2} \mathrm{O}_{2}$ accumulation might support cell death to pave the way for fungi during their necrotrophic growth stages.

Due to the albino mutation, white leaves of albostrians contain only traces of chlorophyll and carotenoids. The redox metabolism of the leaves is perturbed by either respiratory or photo-oxidative stress (Boldt et al. 1997). Therefore, we addressed the question of whether changes in the redox status may explain the altered resistance status of white leaves. Along with a thorough cytological analysis of the interaction of Bipolaris sorokiniana with green and white leaves, we provide a first survey on the expression status of a set of candidate genes which are known to have a role in redox metabolism and cell death regulation and, hence, are supposed to affect plant defense.

\section{RESULTS}

\section{Fungal attack and plant defense.}

We investigated defense reactions exhibited by moderately susceptible barley cv. Haisa and its supersusceptible barley albino mutant albostrians at 20 and $40 \mathrm{~h}$ after inoculation (hai). A general scheme of the type of observed host responses is shown in Figure 1.

In general, epidermal cells were penetrated by 20 hai, and $B$. sorokiniana formed up to seven appressorium-like structures per germinated conidium. We defined successful plant infection as the escape of the fungus out of the first penetrated epidermal cell into the mesophyll tissue. By parallel use of ink to stain extracellular fungal structures, and the fluorescent brightener calcofluor to stain inter- and intracellular fungal structures, we could distinguish pre- and postinfectional host responses. Preinfectional defense was attributed to papilla-like cell wall apposition (CWA) (Fig. 2A), $\mathrm{HR}$, or both, resulting in failure of epidermis cell penetration. In some cases, fungal attack was stopped only by postpenetration HR (PPHR) (Fig. 2B and C), which caused an arrest of fungal growth after penetration into a single epidermal cell by a subsequent cell death reaction. In many cases, preinfectional epidermal defense reactions were unsuccessful, and the fungus entered the mesophyll tissue (Fig. 2D). To detect quantitative differences in fungal spreading within the mesophyll, we defined a spreading factor by assessing the range of the most distant tips of inter- and intracellular hyphae at one infection site (Fig. 2D). Fungal spreading correlated positively with the accumulation of $\mathrm{H}_{2} \mathrm{O}_{2}$ (Fig. 2D) and the number of collapsed mesophyll cells in green tissue (data not shown).

All interaction sites showed strong blue-light induced yellow autofluorescence in CWA or over whole cells, the latter being indicative of HR (Kumar et al. 2002). Autofluorescence correlated closely with subcellular and whole-cell accumulation of $\mathrm{H}_{2} \mathrm{O}_{2}$ as visualized upon injection of 3,3'-diaminobenzidine (DAB) into excised leaf segments by reddish-brown DAB polymers.

\section{Albostrians is supersusceptible to $B$. sorokiniana.}

Ten days after inoculation of the different types of albostrians first leaves, white leaves were overgrown completely with sporulating B. sorokiniana mycelium (Fig. 2E). Massive fungal growth finally resulted in leaf collapse. This supersusceptible phenotype was exhibited exclusively by white leaves. Significantly, and in clear contrast to green and striped leaves, white leaves did not develop brownish lesions, the typical leaf spot blotch symptom (Fig. 2E).

Notably, microscopic inspection revealed no significant differences in fungal infection rates on the different types of albostrians leaves. At 40 hai, approximately $60 \%$ of the appressoria led to successful infection on all albostrians leaves (data not shown). White leaves showed a slightly reduced effectiveness of CWA. However, as a consequence of higher penetration frequencies, the frequency of PPHR increased accordingly when compared with green leaves (Fig. 3). Supersusceptibility of white leaves was reflected clearly by extremely enhanced fungal spreading within the mesophyll tissue (Fig. 2F). By 40 hai, the spreading factor in white leaves amounted to approximately $1,100 \mu \mathrm{m}$, corresponding to 20 mesophyll cells spanned by the fungus, as compared with $300 \mu \mathrm{m}$ in the other leaves (Fig. 4). This suggests that supersusceptibility is based on an undamped fungal spreading initiated between 20 and 40 hai, once the fungus entered into mesophyll tissue.

We addressed the question of whether extreme spreading of the fungus correlates with cell death and collapse. Attacked mesophyll cells in white leaves showed only diffuse DAB staining and autofluorescence (Fig. 2F through $\mathrm{H}$ ). In striped leaves, DAB staining of mesophyll cells was tightly restricted to green tissue, even if mycelium from one infection site covered green and white areas. This suggests that $\mathrm{H}_{2} \mathrm{O}_{2}$ accumulation is not a prerequisite for successful fungal spreading in white tissue. Moreover, staining with trypan blue, indicative for cell death, gave a strong reaction in green and a weak reaction in white infected tissue. In contrast, B. sorokiniana-attacked epidermal cells of white leaves often were DAB and trypan blue stainable or showed whole-cell autofluorescence (data not shown; see the author-recommended website).

\section{B. sorokiniana exerts a hemibiotrophic lifestyle.}

We addressed the question of whether $B$. sorokiniana exerts a hemibiotrophic lifestyle (e.g., shows distinct biotrophic and subsequent necrotrophic growth phases). We microscopically screened for living host cells that were penetrated by the fungus by means of $2^{\prime}, 7^{\prime}$-dichlorofluorescin diacetate (FDA). Using this vital stain, we detected living epidermal cells with well-developed fungal hyphae (Fig. 2I). Those cells were judged as intact because they showed continuous cytoplasmic strands and no signs of cytoplasmic granulation or autofluorescence. Actin fibers (as part of the cytoplasmic strands) of attacked cells were focused on the point of attempted fungal penetration, suggesting that the fungus did not kill the attacked cell before penetration (Fig. 2J; author-recommended Internet resources). These observations strongly suggest a hemibiotrophic lifecycle of the pathogen.

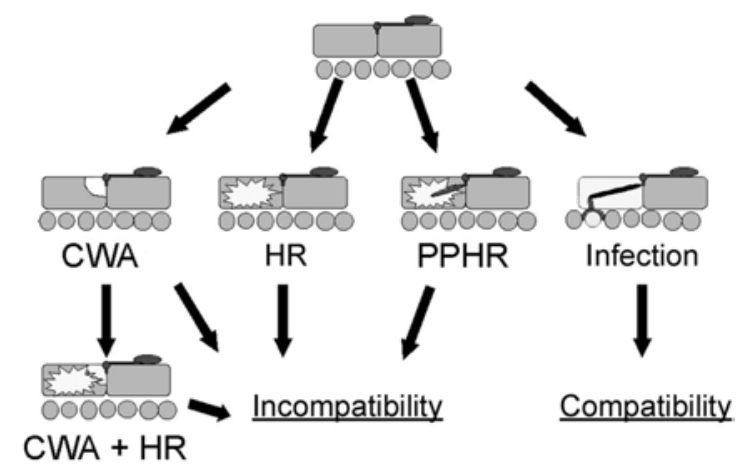

Fig. 1. Host responses in the interaction of cereals with Bipolaris sorokiniana. The fungus often attacks at the anticlinal cell wall. Cell-wall appositions (CWA) and hypersensitive reaction (HR) are features of effective first-line preinfection defense. A second line of preinfectional defense is based on a postpenetration HR (PPHR). Failure of this defense mechanisms leads to compatibility (e.g., fungal infection into the mesophyll tissue and spreading). 


\section{Expression patterns}

of genes involved in plant defense to $B$. sorokiniana.

The results of the cytological study prompted us to comparatively analyze defense and stress-associated gene expres- sion in green and white leaves of albostrians, thereby focusing on genes, which possibly are implicated in the regulation of $\mathrm{H}_{2} \mathrm{O}_{2}$ and cell death. We analyzed a glycolate oxidase $(G L O X)$, a cytosolic ascorbate peroxidase $(c A P X)$, a glutathione S-trans-

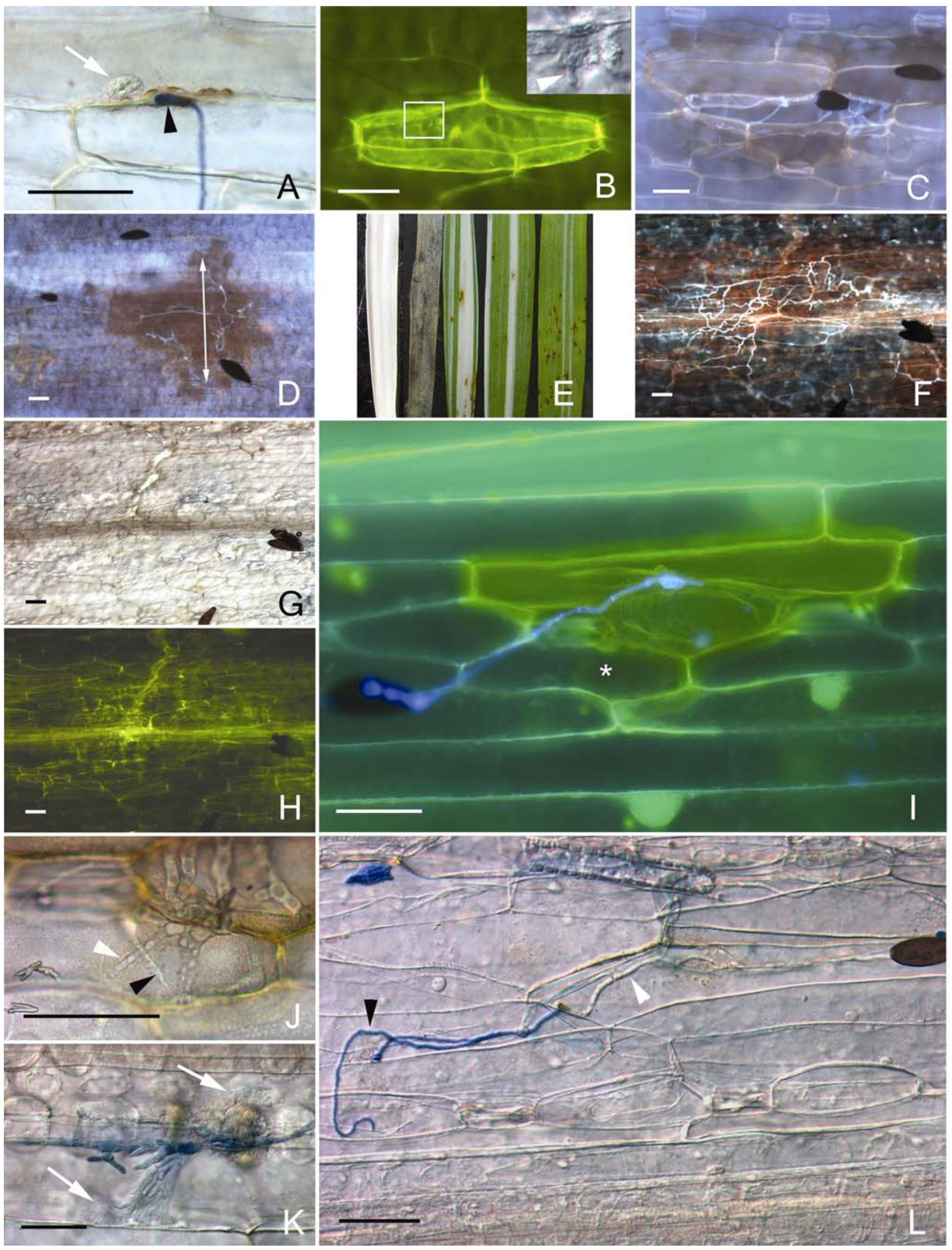


ferase (GST), catalase2 (CAT2), and Bax inhibitor-1 (BI-1). Seven-day-old plants were sprayed with $B$. sorokiniana at 100,000 conidia/ml resulting in an infection density of 100 to 120 conidia/ $\mathrm{cm}^{2}$. Total RNA from leaf samples at 8, 20, and 40 hai were pooled and subjected to reverse-transcription polymerase chain reaction (RT-PCR). Successful infection was verified by macroscopic inspection of infected leaves from the same batch and by expression analysis of pathogenesis-related gene $P R-1 b$. The expression data are displayed in Figure 5. $c A P X, G S T$, and $B I-1$ were more strongly expressed in white than in green leaves, suggesting that an enhanced redox and cell death control is associated with supersusceptibility and symptomless growth of the hemibiotrophic B. sorokiniana. $C A T 2$ was more strongly expressed in green leaves in association with $B$. sorokiniana-induced $\mathrm{H}_{2} \mathrm{O}_{2}$ accumulation. GLOX expression was down regulated in green leaves after pathogen attack, and constitutively down regulated in white leaves. The mRNA abundance of $P R-1 b$ followed the amount of mycelium formed in the leaves, corroborating that this gene is a marker for infection.

\section{DISCUSSION}

We provide a comparative survey of host responses to leaf spot blotch fungus $B$. sorokiniana in differentially reacting barley genotypes. By a microscopic approach, comprising $\mathrm{H}_{2} \mathrm{O}_{2}$ detection by DAB staining and visualizing fungal hyphae by the fluorescent dye calcofluor, we could define preand postinfectional host responses, thereby shedding light on the potential role of the reactive oxygen intermediate $\mathrm{H}_{2} \mathrm{O}_{2}$ in different phases of fungal development. By comparing host responses of the supersusceptible white leaves of the barley mutant albostrians with the moderately susceptible leaves of parent cv. Haisa and green leaves of albostrians, we demonstrate that inhibition of fungal spreading during the supposed necrotrophic mesophyll-based growth phase, rather than a preinfectional, epidermis-based reaction, is the cause for the difference in disease susceptibility.

\section{B. sorokiniana is a hemibiotrophic fungus.}

Calcofluor-based staining of fungal infection structures enabled us to quantitatively assess fungal spreading within the different leaf tissues. Mesophyll tissue necrotization was closely associated with successful fungal infestation, whereby necrotization preceded fungal inter- and intracellular growth. This suggests involvement of $B$. sorokiniana toxins in meso- phyll spreading. This accords with former results of Kumar and associates (2001), who observed mesophyll cell collapse after injection of toxic B. sorokiniana culture filtrate into barley first leaves. Epidermal cells often survived initial $B$. sorokiniana penetration, indicating that toxins may play a role only at late interaction stages rather than in the earlier penetration process. Importantly, identification of living though hyphae-containing epidermal cells clearly demonstrates that the fungus exerts a hemibiotrophic lifestyle (Fig. 2I and J).

At some interaction sites, intracellular finger-like and globular hyphae and multicell complexes (Fig. 2K) resemble subcuticular infection structures, so-called stroma, formed by Venturia inaequalis. Extracellularly localized primary and secondary stroma of $V$. inaequalis were suggested to serve for fungal nourishment (Ortega et al. 1998). Thus, it is conceivable that stroma-like structures of $B$. sorokiniana adopt the same task.

\section{Susceptibility versus supersusceptibility.}

The barley albino mutant albostrians turned out to be an excellent tool to study compatibility and incompatibility mechanisms in the barley-B. sorokiniana interaction. The progeny of albostrians self-crosses develop white, striped, and green seedlings (Boldt et al. 1997; Hess et al. 1998). Only white leaves were supersusceptible to $B$. sorokiniana, whereas green and striped leaves, as well as leaves from the parent cv. Haisa, were moderately susceptible.

During fungal development, pre- and postinfectional host responses were triggered starting with formation of CWA (Fig. 2A) and epidermal HR, both preventing initial penetration into the epidermal cell, followed by PPHR, hindering infection of and spreading within the mesophyll (Fig. 1). PPHR, resulting in encapsulation of the fungus within an epidermal cell, is a very effective defense mechanism because there was no indication for a subsequent escape at later time points (Fig. 2B and C). Importantly, we did not find a significant difference in the infection rate when comparing supersusceptible white albostrians with moderately susceptible cv. Haisa. Preinfectional defense responses differed, with white leaves showing a reduced frequency of CWA and an enhanced amount of PPHR, possibly mirroring a lower threshold for this defense reaction in white leaves. Thus, supersusceptibility clearly is based on an unrestricted postinfectional spreading once the fungus successfully enters white leaf mesophyll (Figs. 2F and 4). Enhanced spreading is associated with accelerated sporulation, seemingly initiated by 40 hai

Fig. 2. Interaction phenotypes of different barley genotypes with Bipolaris sorokiniana. A, 3,3'-Diaminobenzidine (DAB)-stained cell-wall apposition (CWA) (brown structure) effectively stops penetration attempt by a fungal appressorium (black arrowhead). The nucleus is located nearby the interaction site (white arrow). Extracellular mycelium is ink stained (blue color). B, Postpenetration hypersensitive reaction (PPHR) autofluorescing under blue light in green leaves of albostrians. The epidermal cell shows HR after penetration and arrest of fungal growth. Insert: Magnification of rectangle. Bright field image of acidic ink stained fungal mycelium on the leaf surface and intracellular hyphae (white arrowhead) inside the cell. C, Epifluorescence image of an epidermal cell showing PPHR. Encapsulated intracellular hyphae (calcofluor-stained bluish structures) is stopped from infecting adjacent plant tissue. D, Epifluorescence image with a typical symptom in green leaves of albostrians and barley cv. Haisa (40 h after inoculation [hai]). DAB-calcofluor double stain technique enables the detection of $\mathrm{H}_{2} \mathrm{O}_{2}$ accumulation and fungal intra- and intercellular growth (white structures). $\mathrm{H}_{2} \mathrm{O}_{2}$ accumulation surrounds fungal hyphae in the mesophyll. White line indicates fungal spreading inside the mesophyll. E, Symptoms of B. sorokiniana on different types of albostrians leaves. From left to right: White leaf (control), white leaf (10 days post inoculation [dpi]), striped leaf (40 hai), striped leaf (40 hai), and striped leaf (40 hai). The white leaf is covered entirely with $B$. sorokiniana mycelium and spores by 10 dpi, whereas no spot blotch symptoms were seen by 40 hai (not shown). F, Extreme fungal spreading within white leaves under blue light (40 hai). Fungal intra- and intercellular hyphae are stained with calcofluor (white structures). Epidermal cells show weak reddish-brown DAB staining. DAB staining is not detected in mesophyll cells. G, Bright-field image of F focused on the mesophyll layer. Only traces of DAB staining are detectable in the mesophyll. H, Epifluorescence image of F. Penetrated epidermal cells but not mesophyll cells show autofluorescence. I, Epifluorescence image of living cells responding to B. sorokiniana infection (16 hai) after staining with fluorescin diacetate (FDA). Dead infected cells are dark green. A short cell (asterisk) south of the stomata is penetrated but still alive (see $\mathbf{J}$ for detail). $\mathbf{J}$, Bright-field magnification of I. Intracellular hyphae (white arrowhead) are visible beside an intact cytoplasmic strand (black arrowhead), indicating cell integrity (more details can be seen on the Institute of Phytopathology and Applied Zoology website). K, Finger-like hyphae (white arrows) in a green leaf of albostrians (40 hai). Extracellular mycelium is stained with acidic ink. Some ink has diffused inside the epidermis cell and stained the intracellular hyphae. $\mathbf{L}$, The fungus is initiating sporulation as a fungal hypha (white arrowhead) is growing out of an epidermal cell of a white leaf (40 hai). Extracellular part of the hypha (black arrowhead) is stained with acidic ink. Bar $=60 \mu \mathrm{m}$. 
(Fig. 2L), and finally results in a total leaf coverage with sporulating mycelium by approximately 10 days postinfection (dpi) (Fig. 2E).

Intriguingly, white leaves are not more susceptible to pathogens in general. When we used the powdery mildew fungus Blumeria graminis f. sp. hordei for inoculation experiments, we found that resistance was greatly enhanced in albostrians compared with cv. Haisa (Jain et al. 2004). Enhanced resistance to B. graminis f. sp. hordei was associated with an increased frequency of effective epidermal cell wall appositions and $\mathrm{H}_{2} \mathrm{O}_{2}$ accumulation in white leaves. This situation resembles the ambivalent role the barley Mlo locus exhibits in defense against biotrophic and hemibiotrophic fungi. Although the Mlo wild-type gene governs susceptibility to biotrophic $B$. graminis f. sp. horde $i$ and is required for basal resistance to $\mathrm{Bi}$ polaris sorokiniana, the mutant allele mlo mediates complete resistance to Blumeria graminis f. sp. hordei but enhanced susceptibility to Bipolaris sorokiniana and the hemibiotrophic fungus Magnaporthe grisea (Jarosch et al. 1999; Kumar et al. 2001, 2002). However, the present data do not justify a final conclusion of whether the contrasting responses of white leaves to Blumeria graminis f. sp. hordei and Bipolaris sorokiniana reflect an antagonistic effect of the same mechanism or, alternatively, are independent.

\section{$\mathrm{H}_{2} \mathrm{O}_{2}$ accumulation is linked}

\section{to defense rather than to susceptibility.}

Apparently, $\mathrm{H}_{2} \mathrm{O}_{2}$ formation is associated with distinct plant responses to $B$. sorokiniana. First, $\mathrm{H}_{2} \mathrm{O}_{2}$ accumulates strongly within papilla-like CWAs (Fig. 2A) in B. sorokiniana-attacked epidermal cells (Kumar et al. 2002). This phenomenon first was reported by Thordal-Christensen and associates (1997) in the barley-powdery mildew system and was shown to be
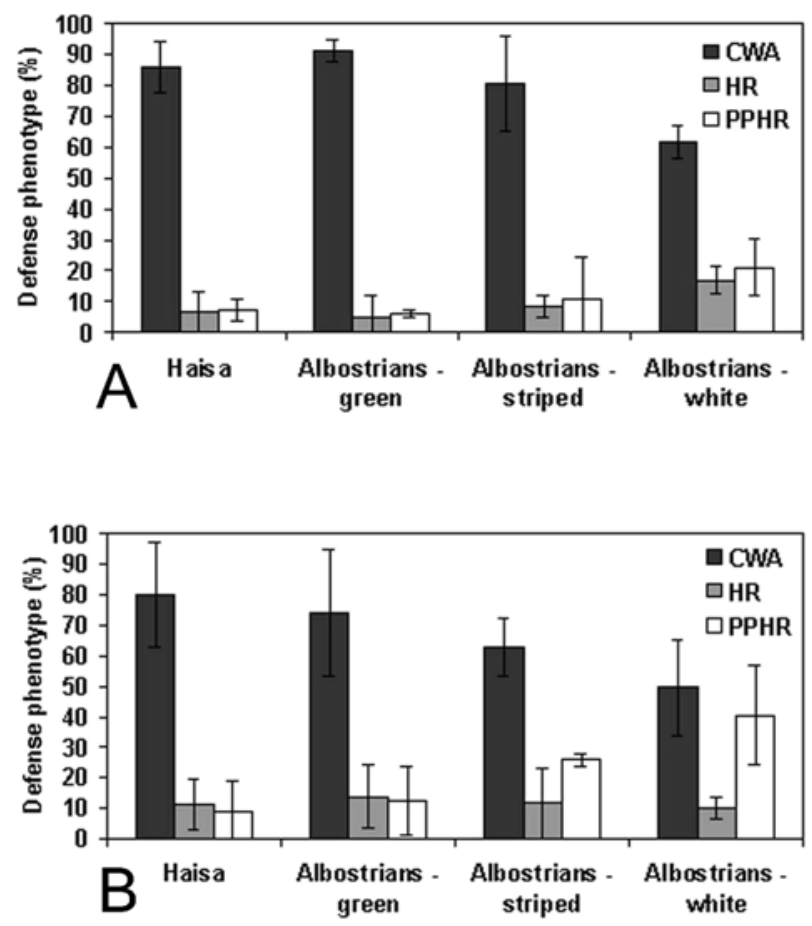

Fig. 3. Frequencies of effective defense mechanisms on cv. Haisa and different leaf types of albostrians. Data were collected at A, $20 \mathrm{~h}$ after inoculation (hai) and B, 40 hai. Cell-wall apposition (CWA), hypersensitive reaction (HR), and postpenetration HR (PPHR) represent preinfection defense mechanisms. Only sites with failed infection are included. The data are based on 240 interaction sites on four leaves per experiment, genotype, and time. The experiment was repeated two times with similar results. Data of one experiment \pm standard deviation are shown. linked to effectiveness of penetration resistance (Hückelhoven and Kogel 2003). Notably, papilla formation and $\mathrm{H}_{2} \mathrm{O}_{2}$ accumulation also is the prominent defense response in white albostrians after powdery mildew attack (Jain et al. 2004). Second, $\mathrm{H}_{2} \mathrm{O}_{2}$ accumulates during epidermal pre- and postpenetration $\mathrm{HR}$, resulting in penetration resistance and encapsulation of the fungus, respectively. Third, $\mathrm{H}_{2} \mathrm{O}_{2}$ strongly accumulates during the necrotrophic phase of $B$. sorokiniana development (i.e., during mesophyll spreading in green leaves) (Fig. 2D). One might speculate that $\mathrm{H}_{2} \mathrm{O}_{2}$ accumulation may support cell death to pave the way for $B$. sorokiniana in its necrotrophic growth stage. However, a judgment of the role of $\mathrm{H}_{2} \mathrm{O}_{2}$ at this point is difficult, because it is not clear whether it accumulates as a cause or a consequence of spreading and possibly toxin-mediated tissue necrotization. The lack of $\mathrm{H}_{2} \mathrm{O}_{2}$ detection in the infected mesophyll tissue of supersusceptible albostrians might hint at a protective rather than pathogenesissupporting function of $\mathrm{H}_{2} \mathrm{O}_{2}$. However, we cannot exclude the possibility that $\mathrm{H}_{2} \mathrm{O}_{2}$ is not necessary for fungal spreading due to the strongly impaired white phenotype. It is noteworthy that we could not unambiguously demonstrate fungus-mediated mesophyll cell death in albostrians by vital staining, and, accordingly, whole-cell autofluorescence was extremely faint (Fig. 2F through $\mathrm{H}$ ). On the macroscopic level, this was reflected by the absence of any typical spot blotch symptoms. However, inoculated white leaves exhibited enhanced electrolyte leakage 40 hai (data not shown). This might indicate enhanced cell death inside the white tissue but, because increased leakage was absent in inoculated green and striped leaves, it alternatively might reflect elevated ion leakage due to cell death independent membrane dysfunction in massively infested tissues. It is tempting to speculate that B. sorokiniana exhibits an elongated biotrophic growth phase in white leaves. Absence of typical disease symptoms and obvious cell death reactions in white mesophyll might be explained by a lack of $\mathrm{H}_{2} \mathrm{O}_{2}$ accumulation in chloroplast that normally is provoked by $B$. sorokiniana in green barley (Kumar et al. 2001). The observation that chloroplasts in attacked green leaves are DABpositive points to the Mehler reaction as the source for $\mathrm{H}_{2} \mathrm{O}_{2}$ during necrotrophic growth of $B$. sorokiniana in the light. This notion is further supported by the detection of $\mathrm{O}_{2}{ }^{--}$as the primary product of the Mehler reaction in chloroplasts of cells surrounding spot blotch lesions (data not shown).

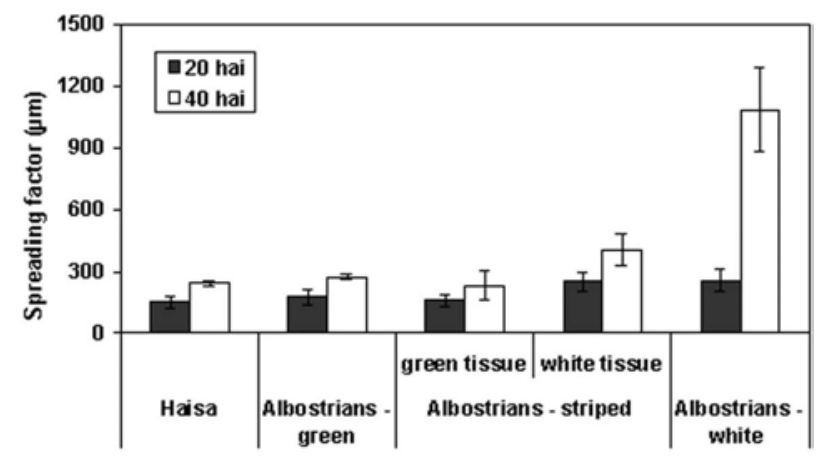

Fig. 4. Inter- and intracellular growth of Bipolaris sorokiniana on cv. Haisa and different leaf types of albostrians. The amount of fungal growth is judged by the spreading factor (in $\mu \mathrm{m}$ ). The spreading factor was determined 20 and $40 \mathrm{~h}$ after inoculation (hai) and is based on 28 to 40 infection sites per leaf, depending on the infection rate, and four leaves per genotype. Cell-wall apposition (CWA), hypersensitive reaction (HR), and postpenetration HR (PPHR) represent preinfection defense mechanisms. The experiment was repeated two times with similar results. Data of one experiment \pm standard deviation are shown. 
Expression analysis of defense- and stress-related genes.

To gain a first overview over gene expression in supersusceptible albostrians, we compared a set of candidate genes in green and white leaves inoculated with B. sorokiniana (Fig. 5). Two genes, CAT2 and GLOX, were down regulated in white leaves. CAT2 expression correlated closely with infectionrelated accumulation of $\mathrm{H}_{2} \mathrm{O}_{2}$ in green leaves. Low CAT2 transcript abundance in white leaves could be explained by the loss of peroxisome abundance and dysfunction. GLOX produces $\mathrm{H}_{2} \mathrm{O}_{2}$ in peroxisomes during photorespiration. GLOX was strongly down regulated in green leaves after inoculation with $B$. sorokiniana and constitutively down regulated in white leaves, which corroborates earlier results of Boldt and associates (1997). This suggests that photorespiration is not the main source for $B$. sorokiniana-induced $\mathrm{H}_{2} \mathrm{O}_{2}$ accumulation in the mesophyll of green leaves.

It previously was reported that defense and stress-related genes are constitutively active in unchallenged white leaves of albostrians (Hess et al. 1998). Unexpectedly, higher constitutive expression of most defense and stress-related genes in white compared with green leaves did not result in higher resistance to $B$. sorokiniana. The level of $B$. sorokiniana-induced $P R-1 b$ expression correlated positively with the infection rate, and not with defense reactions, because it was much stronger in albostrians white leaves. $c A P X, G S T$, and $B I-1$ were more strongly expressed in white compared with green leaves, suggesting that an enhanced redox- and cell death control is associated with supersusceptibility and symptomless growth of the hemibiotrophic B. sorokiniana. Enhanced $c A P X$ and GST accumulation also might balance lower catalase activity. Notably, $c A P X$ was not induced by $B$. sorokiniana in green leaves, showing that its expression did not correlate with the amount of $\mathrm{H}_{2} \mathrm{O}_{2} . \mathrm{BI}-1$ shows pathogen-responsive expression in green leaves. $B I-1$ is a cell death and defense suppressor that is involved in powdery mildew resistance of barley (Hückelhoven et al. 2003; Matsumura et al. 2003; Sanchez et al. 2000), and also was induced in green leaves after attack by $B$. graminis $\mathrm{f}$. sp. hordei (Hückelhoven et al. 2003; Jain et al. 2004). Interestingly, the race-nonspecific penetration resistance of mlo5-barley to Blumeria graminis f. sp. hordei is suppressed by overexpression of $B I-1$ supporting biotrophy (Hückelhoven et al. 2003). Thus, enhanced expression of $B I-1$ in white leaves might be involved in suppression of cell death and symptom development. In this regard, it is interesting that the cell death suppressor Mlo also is highly expressed in white leaves that show a reduced frequency of mesophyll HR in response to $B$. graminis f. sp. hordei (Jain et al. 2004). We speculate that symptomless growth of $B$. sorokiniana in white leaves could reflect unrestricted biotrophic growth. To what extent necrotrophic growth in green tissue represents a fungal strategy to counteract cell death-related plant defense or necrotrophy mirrors a more or less effective plant defense response has to be answered.

\section{MATERIALS AND METHODS}

Plants, pathogen, and inoculation.

Barley (Hordeum vulgare L.) mutant albostrians and parent cv. Haisa were used. For molecular analysis, plants were grown in a growth chamber with a cycle of $23^{\circ} \mathrm{C}$, day and $18^{\circ} \mathrm{C}$, night, $60 \%$ relative humidity $(\mathrm{RH})$, and a photoperiod of $16 \mathrm{~h}\left(240 \mu \mathrm{mol} \mathrm{m} \mathrm{m}^{-2} \mathrm{~s}^{-1}\right.$ photon flux density). Seven-day-old plants were inoculated by spraying a spore suspension containing 100,000 spores $\mathrm{ml}^{-1}$ that results in 100 to $120 \mathrm{co}-$ nidia $/ \mathrm{cm}^{2}$ per leaf. The isolation and origin of the Bipolaris sorokiniana culture KN2 (teleomorph: Cochliobolus sativus; culture collection of the Institute of Phytopathology and Applied
Zoology, Heinrich-Buff-Ring 26-32, 35392 Giessen, Germany) was described previously (Kumar et al. 2001). In parallel, control plants were sprayed with Tween 20 water (1:5000 vol/ vol). After inoculation and control treatment, plants were placed in a transparent plastic box lined with Whatman filter paper and closed with a lid guaranteeing a $\mathrm{RH}$ of $>95 \%$. The boxes were put back in the same growth chamber used for plant growing.

For cytological studies, plants were grown in a growth chamber with a cycle of $18^{\circ} \mathrm{C}$ day and night, $60 \% \mathrm{RH}$, and a photoperiod of $16 \mathrm{~h}\left(60 \mu \mathrm{mol} \mathrm{m} \mathrm{m}^{-2} \mathrm{~s}^{-1}\right.$ photon flux density).

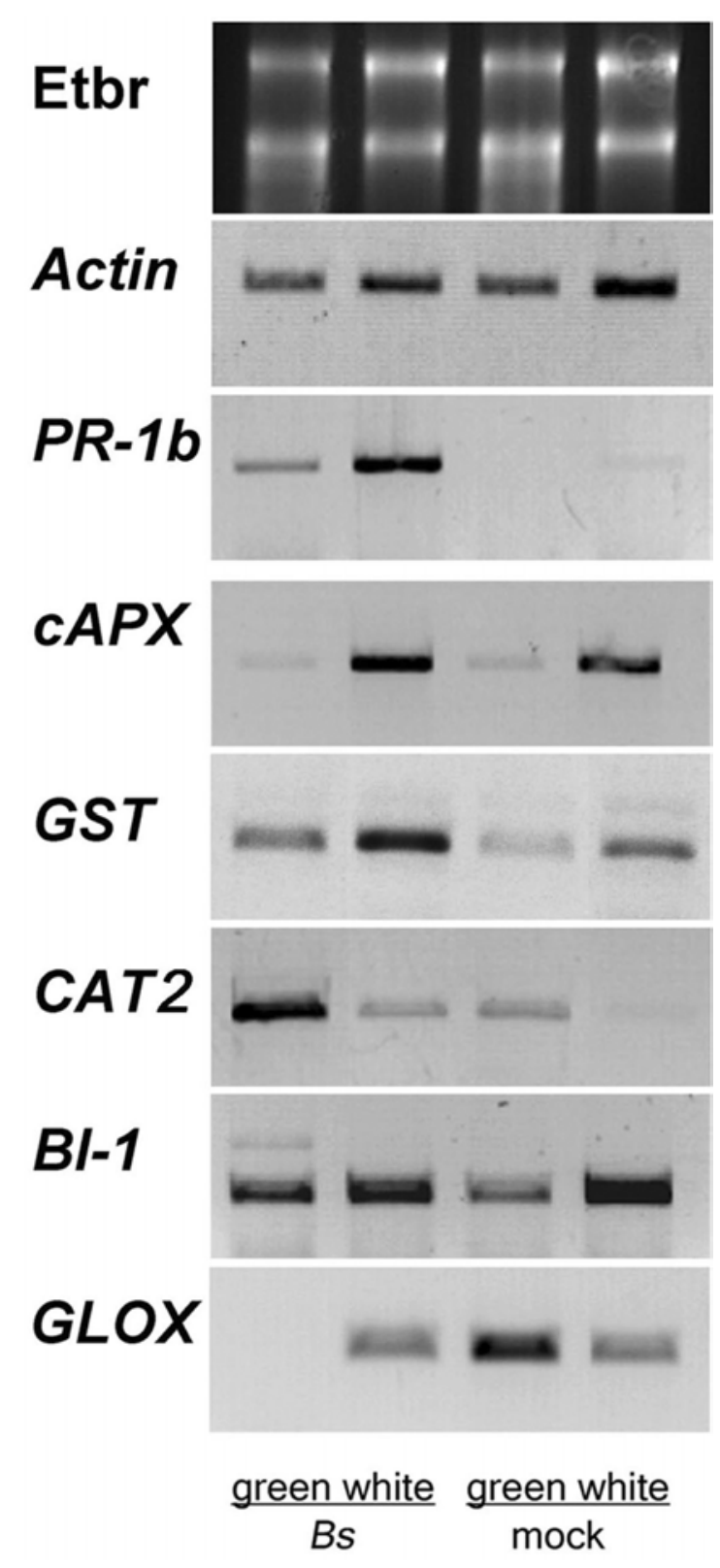

Fig. 5. Reverse transcription-polymerase chain reaction (RT-PCR) analysis of stress-related gene transcripts after inoculation of white and green albostrians leaves with Bipolaris sorokiniana. Transcript accumulation was analyzed using RNA-pools extracted from green and white leaves containing equal amounts of RNA from 8, 20, and $40 \mathrm{~h}$ after inoculation (hai) with $B$. sorokiniana. Additionally, mock-treated $(8,20$, and 40 hai) green and white leaves were analyzed. RT-PCR products were detected in agarose gels after separation and staining with $\mathrm{EtBr}$ (inverted positives shown). Equal loading of RT-PCR tubes ( $1 \mu \mathrm{g}$ of RNA) was confirmed by EtBr staining of rRNAs in separated check gels and by the constitutively expressed actin. Independent repetition of the experiments led to very similar results. 
Seven-day-old leaf segments were placed onto wet Whatman filter paper and inoculated with 50,000 spores $\mathrm{ml}^{-1}$. The leaf segments were incubated on $0.7 \%$ water agar (benzimidazol at $40 \mathrm{mg} \mathrm{liter}^{-1}$ ) in closed plastic boxes (>95\% RH) for 20 and 40 $\mathrm{h}$, respectively. The boxes were transferred in a growth chamber with a cycle of $24^{\circ} \mathrm{C}$ day and night and a photoperiod of $16 \mathrm{~h}\left(30 \mu \mathrm{mol} \mathrm{m} \mathrm{m}^{-2} \mathrm{~s}^{-1}\right.$ photon flux density).

\section{RNA extraction and RT-PCR}

The OneStep RT-PCR kit (Qiagen, Hilden, Germany) was used for semiquantitative RT-PCR following the manufacturer's instructions and as reported (Hückelhoven et al. 2001). Total RNA was extracted from five leaf segments $(8 \mathrm{~cm}$ long) using RNA extraction buffer (Peqlab, Erlangen, Germany) according to the manufacturer's instruction. RNAs were isolated at $0,8,20$, and 40 hai with $B$. sorokiniana adjusted to a concentration of $1 \mu \mathrm{g} \mu$ liter $^{-1}$ and pooled. In parallel, RNA was extracted from leaves sprayed with Tween 20 water (1:5000 $\mathrm{vol} / \mathrm{vol}$ as a control). The RNA pools from green and white leaves of albostrians were used as templates. Primers for actin, $c A P X$, and $B I-1$ previously were published (Hess and Börner 1998; Hückelhoven et al. 2001). Further primers were 5'GGCGTCAACACCTACACCTT-3' (5'primer) and 5'-TGGA GAGGAAGTCGATCCAG-3' (3'primer) to obtain a 790-bp CAT2 fragment (barley Cat2); 5'-GAAGCTGTACGGGAT GATGCT-3' (5'primer) and 5'-GTGGTTGGCGTCGGCGAG CGT-3' (3'primer) to obtain a 490-bp GST fragment; and 5'GCCCAAGCTAGTCATCTTGC-3' (5'primer) and 5'-TGGT TTCTGTCCAACGATGT-3' (3'primer) to obtain a 490-bp $P R$ $1 b$ fragment (Bryngelsson et al. 1994). We designed primers, 5'-AGCTGGAAGGACGTCAAGTG-3' (5'primer) and 5'-GT GATGTCGCTGAGCTTGGT-3' (3'primer), of a barley clone being $87 \%$ identical to a rice homologue to obtain a 416 -bp GLOX.

\section{Microscopy of defense mechanisms and cytochemistry.}

$\mathrm{H}_{2} \mathrm{O}_{2}$ was detected using the DAB method (D-8001; SigmaAldrich Chemie $\mathrm{GmbH}$, Steinheim, Germany,) as described previously (Thordal-Christensen et al. 1997). DAB at $1 \mathrm{mg} / \mathrm{ml}$ was dissolved in water $(\mathrm{pH} \mathrm{3.8,} \mathrm{HCl})$ and injected into barley first leaves $2 \mathrm{~h}$ before fixation.

Intra- and intercellular fungal hyphae were stained using fluorescent brightener 28 (Calcofluor, F-6259, Sigma) (Rohringer et al. 1977). Leaf fixation and microscopy were conducted as described (Hückelhoven and Kogel 1998). Leaves were fixed in TCA $(0.15 \%$ trichloroacetic [wt/vol] in ethylalcohol:chloroform [4:1; vol/vol]). Fixed-leaf segments were washed $2 \times 15 \mathrm{~min}$ with $50 \%$ ethanol, $2 \times 15$ min with $50 \mathrm{mM} \mathrm{NaOH}$, and $3 \times 10 \mathrm{~min}$ with $\mathrm{H}_{2} \mathrm{O}$ dest., subsequently followed by $30 \mathrm{~min}$ of incubation in $0.1 \mathrm{M}$ Tris/ $\mathrm{HCl}(\mathrm{pH} \mathrm{8.5)}$. After this step, segments were stained for 5 min with $0.3 \%$ (wt/vol) calcofluor and finally washed $4 \times 10 \mathrm{~min}$ with distilled water.

Whole-cell and subcellular autofluorescence were observed by epifluorescence microscopy (excitation filter $485 \mathrm{~nm}$, dichoric mirror $510 \mathrm{~nm}$, barrier filter $520 \mathrm{~nm}$ ). Calcofluorstained hyphae were observed by fluorescence microscopy (excitation filter $368 \mathrm{~nm}$, dichoric mirror $385 \mathrm{~nm}$, barrier filter $420 \mathrm{~nm}$ ). All microscopy was done with an Axioplan microscope (Zeiss, Jena, Germany). At least 60 to 70 interaction sites were determined per leaf segment. Four leaf segments were analyzed in at least two independent experiments. Interaction sites were defined as locations where a fungal appressorium caused a visible plant response. Defense reactions were evaluated in all epidermal cell types except hair cells.

Trypan blue staining was used to detect cell death in epidermal and mesophyll tissue according to Kmecl and associates
(1995). FDA (D-6883; Sigma) was used to detect living cells according to Hadwiger and associates (1995). Initially, a stock solution with FDA at $5 \mathrm{mg} / \mathrm{ml}$ of acetone was diluted to a $2 \%$ staining solution with $10 \mathrm{mM}$ potassium phosphate buffer $(\mathrm{pH}$ 6.4) containing $0,02 \%$ membrane wetting solution (Silwet L-77; Gibco BRL-Life Technologies GmbH, Karlsruhe, Germany). The FDA staining solution was vacuum infiltrated in detached leaves and immediately analyzed. Leaf segments were immersed in $0.3 \%$ calcofluor solution to stain extracellular fungal hyphae. The leaf cells collapsed due to FDA staining after 2 to $3 \mathrm{~h}$.

\section{ACKNOWLEDGMENTS}

This work was supported by a grant from the Deutsche Forschungsgemeinschaft (DFG), Bonn, and the Deutsche Volkswagen Stiftung, Wolfsburg. We thank T. Börner and W. Hess (Humboldt University, Berlin, Germany) for providing seed of albostrians and cv. Haisa; and M. Fischer for technical assistance.

\section{LITERATURE CITED}

Apoga, D., Akesson, H., Jansson, H.-B., and Odham, G. 2002. Relationship between production of the phytotoxin prehelminthosporol and virulence in isolates of the plant pathogenic fungus Bipolaris sorokiniana. Eur. J. Plant Pathol. 108:519-526.

Boldt, R., Koshuchowa, S., Gross, W., Börner, T., and Schnarrenberger, C. 1997. Decrease in glycolate pathway enzyme activities in plastids and peroxisomes of the albostrians mutant of barley (Hordeum vulgare L.). Plant Sci. 124:33-40.

Briquet, M., Vilret, D., Goblet, P., Mesa, M., and Eloy, M.-C. 1998. Plant cell membranes as biochemical targets of the phytotoxin helminthosporol. J. Bioenerg. Biomembr. 30:285-295.

Bryngelsson, T., Sommer-Knudsen, J., Gregersen, P. L., Collinge, D. B., Ek, B., and Thordal-Christensen, H. 1994. Purification, characterization, and molecular cloning of basic PR-1-type pathogenesis-related proteins from barley. Mol. Plant-Microbe Interact. 7:267-275.

Dehne, H.-W., and Oerke, E.-C. 1985. Investigations on the occurrence of Cochliobolus sativus on barley and wheat. II. Infection, colonization and damage of stems and leaves. J. Plant Dis. Prot. 92:606-617.

Dubin, H. J., and Ginkel, V. 1991. The status of wheat diseases in warm areas of south Asia: An update. Pages 353-359 in: Wheat in Heat Stressed Environments: Irrigated Dry Areas and Rice-Wheat Farming Systems. D. A. Saunder and G. P. Hettel, eds. International Maize and Wheat Improvement Center, Mexico, D.F., Mexico

Govrin, E. M., and Levine, A. 2000. The hypersensitive response facilitates plant infection by the necrotrophic pathogen Botrytis cinerea. Curr. Biol. 10:751-757.

Grant, J. J., and Loake, G. J. 2000. Role of reactive oxygen intermediates and cognate redox signaling in disease resistance. Plant Physiol. 124:21-29.

Hadwiger, L. A., Chang, M.-M., and Parsons, M. A. 1995. Fusarium solani DNase is a signal for increasing expression of nonhost disease resistance response genes, hypersensitivity, and pisatin production. Mol. Plant-Microbe Interact. 8:871-879.

Hess, W. R., and Börner, T. 1998. Cloning and characterization of expression of cytosolic ascorbate peroxidase cDNA from barley (Accession No. AJ006358). (PGR98-135) Plant Physiol. 118:329.

Hess, W. R., Golz, R., and Börner, T. 1998. Analysis of randomly selected cDNAs reveals the expression of stress- and defense-related genes in the barley mutant albostrians. Plant Sci. 133:191-201.

Hückelhoven, R., Dechert, C., and Kogel, K.-H. 2003. Overexpression of barley BAX Inhibitor 1 induces breakdown of mlo-mediated penetration resistance to Blumeria graminis. Proc. Natl. Acad. Sci. U.S.A. 100:5555-5560.

Hückelhoven, R., Dechert, C., Trujillo, M., and Kogel, K.-H. 2001. Differential expression of putative cell death regulator genes in near-isogenic, resistant and susceptible barley lines during interaction with the powdery mildew fungus. Plant Mol. Biol. 47:739-748.

Hückelhoven, R., Fodor, J., Preis, C., and Kogel, K.-H. 1999. Hypersensitive cell death and papilla formation in barley attacked by the powdery mildew fungus are associated with $\mathrm{H}_{2} \mathrm{O}_{2}$ but not with salicylic acid accumulation. Plant Physiol. 119:1251-1260.

Hückelhoven, R., and Kogel, K.-H. 1998. Tissue-specific superoxide generation at interaction sites in resistant and susceptible near-isogenic barley lines attacked by the powdery mildew fungus (Erysiphe graminis f. sp. hordei). Mol. Plant-Microbe Interact. 11:292-300. 
Hückelhoven, R., and Kogel, K.-H. 2003. Reactive oxygen intermediates in plant-microbe interactions: Who is who in powdery mildew resistance? Planta 216:891-902.

Jain, S. K., Langen, G., Hess, W., Börner, T., Hückelhoven, R., and Kogel, K.-H. 2004. The white barley mutant albostrians shows enhanced resistance to the biotroph Blumeria graminis f. sp. hordei. Mol. PlantMicrobe Interact. In press.

Jarosch, B., Kogel, K.-H., and Schaffrath, U. 1999. The ambivalence of the barley Mlo locus: Mutations conferring resistance against powdery mildew (Blumeria graminis f. sp. hordei) enhance susceptibility to the rice blast fungus Magnaporthe grisea. Mol. Plant-Microbe Interact. 12:508-514.

Kmecl, A., Mauch, F., Winzeler, M., Winzeler, H., and Dudler, R. 1995. Quantitative field resistance of wheat to powdery mildew and defense reactions at the seedling stage: Identification of a potential marker. Physiol. Mol. Plant Pathol. 47:185-199.

Kumar, J., Hückelhoven, R., Beckhove, U., Nagarajan, S., and Kogel, K.H. 2001. A compromised Mlo pathway affects the response of barley to the necrotrophic fungus Bipolaris sorokiniana (teleomorph: Cochliobolus sativus) and its toxins. Phytopathology 91:127-133.

Kumar, J., Schäfer, P., Hückelhoven, R., Langen, G., Baltruschat, H., Stein, E., Nagarajan, S., and Kogel, K.-H. 2002. Bipolaris sorokiniana, a cereal pathogen of global concern: Cytological and molecular approaches towards better control. Mol. Plant Pathol. 3:185-195.

Lamb, C., and Dixon, R. A. 1997. The oxidative burst in plant disease resistance. Annu. Rev. Plant Physiol. Plant Mol. Biol. 48:251-275.

Levine, A., Tenhaken, R., Dixon, R., and Lamb, C. 1994. $\mathrm{H}_{2} \mathrm{O}_{2}$ form the oxidative burst orchestrates the plant hypersensitive disease resistance response. Cell 79:583-593.

Matsumura, H., Nirasawa, S., Kiba, A., Urasaki, N., Saitoh, H., Ito, M. Kawai-Yamada, M., Uchimiya, H., and Terauchi, R. 2003. Overexpression of Bax inhibitor suppresses the fungal elicitor-induced cell death in rice (Oryza sativa L.) cells. Plant J. 33:425-434.
Mullineaux, P., Ball, L., Escobar, C., Karpinska, B., Creissen, G., and Karpinski, S. 2000. Are diverse signaling pathways integrated in the regulation of Arabidopsis antioxidant defence gene expression in response to excess excitation energy? Philos. Trans. R. Soc. Lond. B 355:1531-1540.

Neill, S., Desikan, R., and Hancock, J. 2002. Hydrogen peroxide signaling. Curr. Opin. Plant Biol. 5:388-395.

Ortega, F., Steiner, U., and Dehne, H.-W. 1998. Induced resistance to apple scab: Microscopic studies on the infection cycle of Venturia inaequalis (Cke.) Wint. J. Phytopathol. 146:399-405.

Rohringer, R., Kim, W. K., Samborski, D. J., and Howes, N. K. 1977. Calcofluor: An optical brightener for fluorescence microscopy of fungal plant parasites in leaves. Phytopathology 67:808-810.

Sanchez, P., de Torres Zabala, M., and Grant, M. 2000. AtBI-1, a plant homologue of Bax inhibitor-1, suppresses Bax-induced cell death in yeast and is rapidly upregulated during wounding and pathogen challenge. Plant J. 21:393-399.

Thordal-Christensen, H., Zhang, Z., Wei, Y., and Collinge, D. B. 1997. Subcellular localization of $\mathrm{H}_{2} \mathrm{O}_{2}$ in plants. $\mathrm{H}_{2} \mathrm{O}_{2}$ accumulation in papillae and hypersensitive response during the barley-powdery mildew interaction. Plant J. 11:1187-1194.

von Gönner, M., and Schlösser, E. 1993. Oxidative stress in interactions between Avena sativa L. and Drechslera spp. Physiol. Mol. Plant Pathol. 42:221-234.

von Tiedemann, A. 1997. Evidence for a primary role of active oxygen species in induction of host cell death during infection of bean leaves with Botrytis cinerea. Physiol. Mol. Plant Pathol. 50:151-166.

\section{AUTHOR-RECOMMENDED INTERNET RESOURCE}

Justus Liebig-Universitaet Giessen Institute of Phytopathology and Applied Zoology website: www.uni-giessen.de/fbr09/ipaz/ipaz/home.htm; for access to scientific movies and the picture gallery, click "Research" and then "Pictures and Movies" 